Supporting information

\title{
Reversibility of Noble Metal-Catalyzed Aprotic Li-O Batteries
}

Shunchao Ma, ${ }^{1,2}$ Yang Wu, ${ }^{*}, 3$ Jiawei Wang, ${ }^{1}$ Yelong Zhang, ${ }^{1,2}$ Yantao Zhang, ${ }^{1,2}$ Xinxiu Yan, ${ }^{1}$ Yang Wei, ${ }^{3}$ Peng Liu, ${ }^{3}$ Jiaping Wang, ${ }^{3}$ Kaili Jiang, ${ }^{3}$ Shoushan Fan, ${ }^{3}$ Ye Xu,${ }^{4}$ and Zhangquan Peng ${ }^{*}, 1$

${ }^{1}$ State Key Laboratory of Electroanalytical Chemistry, Changchun Institute of Applied Chemistry, Chinese Academy of Sciences, Changchun 130022, P. R. China

${ }^{2}$ University of Chinese Academy of Sciences, Beijing 100039, P. R. China

${ }^{3}$ Department of Physics and Tsinghua-Foxconn Nanotechnology Research Center, Tsinghua University, Beijing 100084, P. R. China

${ }^{4}$ Department of Chemical Engineering, Louisiana State University, Baton Rouge, Louisiana 70803, USA

*Corresponding Authors

E-mail:wuyang.thu@gmail.com(Yang Wu), zqpeng@ciac.ac.cn (ZhangquanPeng) 


\section{Experime ntal Section}

\section{Materials Preparation and Characterizations:}

The preparation of noble metal $(\mathrm{Ru}$ and $\mathrm{Pd})$-catalyzed carbon nanotube $(\mathrm{CNT})$ electrodes was performed with a lab-designed apparatus. Si wafers $(2.5 \mathrm{~cm}$ wide $)$, on which spinnable super-aligned CNT arrays were grown in a low-pressure chemical vapor deposition system, were placed at one end of the chamber. CNT films were directly spun from such CNT arrays and fixed on a horizontally mounted Cu cylinder. The sputtering gun was vertically placed under the CNT film with a gap of $5 \mathrm{~cm}$. The preparation procedure was sketched in Figure S1a. A servomotor was used to control the spinning speed. For the sample preparation, the entire system was vacuum-pumped down to a pressure $<3 \times 10^{-3} \mathrm{~Pa}$ before $10 \mathrm{sccm}$ Ar was back filled to reach a pressure of $0.2 \mathrm{~Pa}$ for magnetron sputtering. High purity $\mathrm{Ru}$ and $\mathrm{Pd}$ metal plates (75 $\mathrm{mm}$ in diameter) were used as the targets. During the sputtering process, the drawing speed of CNT film was fixed at 2 or $3 \mathrm{~cm} / \mathrm{s}$ to ensure the uniformity of $\mathrm{Ru}$ and Pd particle sizes and the sputtering power was maintained at $50 \mathrm{~W}$. After the $\mathrm{Cu}$ cylinder span for 200 revolutions, the sputtering was stopped and the CNT sample, decorated with $\mathrm{Ru}$ or $\mathrm{Pd}$, was taken out and cut into square sheets with a razor blade, as shown in Figure S1b. The pure CNT fabrics were prepared by the same means but without turning on the sputtering unit.

The microstructures of the obtained cathodes were characterized using an FEI Sirion 200 scanning electron microscope (SEM) operating at $10 \mathrm{kV}$, and an FEI Tecnai G2F20 transmission electron microscope (TEM) operating at $200 \mathrm{kV}$ equipped 
with energy-dispersive X-ray spectroscopy (EDX) analyzers. The actual loading of noble metal was determined with thermal gravimetric analysis (TGA) on a Perkin-Elmer analyzer from room temperature to $800{ }^{\circ} \mathrm{C}$ at a heating rate of 10 ${ }^{\circ} \mathrm{C} / \mathrm{min}$ in air. The ashes were analyzed on a Rigaku D/max $2500 \mathrm{PC}$ diffractometer $\left(\mathrm{Cu} \mathrm{K} \alpha_{1}\right.$ radiation) and it turned out that $\mathrm{RuO}_{2}(\mathrm{PdO})$ is the only product for $\mathrm{Ru}-\mathrm{CNT}$ (Pd-CNT) samples. Fourier transform infrared spectroscopy (FTIR) were carried out on a Nicolet 6700 spectrometer for discharged/recharged electrodes. The X-ray diffraction (XRD) patterns for pristine/discharged cathodes were performed on a Bruker D8 ADVANCE X-ray diffractometer using $\mathrm{Cu} \mathrm{K \alpha}(\lambda=1.54 \AA)$ radiation. During measurements, all the discharged cathodes were sealed into a homemade container without exposing to the atmosphere. Raman Spectroscopy was performed by using a customized LabRAM HR Evolution Raman system (HORIBA Scientific) with an excitation wavelength of $532 \mathrm{~nm}$.

Electrochemical Measurements of the Aprotic Li-O $\mathbf{O}_{2}$ Cells. The electrochemical performances of the $\mathrm{Li}_{2} \mathrm{O}_{2}$ cells were carried out using a Swagelok-type cell. A piece of CNT fabrics was directly used as air $\mathrm{O}_{2}$ cathode, which was shown in Figure S1b. The mass of each air electrode was approximate $0.2 \mathrm{mg}$. The $\mathrm{Li}-\mathrm{O}_{2}$ cell assembly was conducted in Ar-filled glove box $\left(\mathrm{H}_{2} \mathrm{O}\right.$ and $\mathrm{O}_{2}$ contents below 0.5 ppm) by successively stacking Li metal foil anode, a electrolyte-soaked glass fiber separator and a CNT-based $\mathrm{O}_{2}$ cathode placed on a stainless steel mesh. A $0.1 \mathrm{M}$ LiTFSI solution in tetraethylene glycol dimethyl ether (TEGDME) was used as the electrolyte. The galvanostatic discharge-charge tests were performed on a LAND CT2001A battery testing system with a fixed capacity of $1000 \mathrm{mAh} / \mathrm{g}_{\text {carbon }}$ in a pure $\mathrm{O}_{2}$ atmosphere. The specific capacity was calculated based on the CNT mass of the cathode. 
The DEMS Measurements of the Aprotic Li-O 2 Cells. A quantitative differential electrochemical mass spectrometry (DEMS) was used to study the noble-metal catalyzed $\mathrm{Li}_{2} \mathrm{O}_{2}$ cells. A home- made $\mathrm{Li}_{2} \mathrm{O}_{2}$ cell with two glued PEEK capillary tubes as purge gas inlet and outlet, which is typically based on the Swagelok cell, was linked to a commercial magnetic sector mass spectrometer (Thermo Fischer) by a specially designed gas purging system. The flow rate of purge gas was typically 5 $\mathrm{mL} / \mathrm{min}$. During the discharging process, a mixture of $\mathrm{Ar} / \mathrm{O}_{2}$ (mass ratio 1:4) was used as the carrier gas for the purpose of quantifying $\mathrm{O}_{2}$ consumption. Ar acts as the internal tracer gas with known constant flux. For charging $\mathrm{Li}^{-} \mathrm{O}_{2}$ cells, high-purity $\mathrm{Ar}$ was used as carrier gas. The DEMS cell assembly resembled that mentioned in the electrochemical measurements part. All the cells were tested at the current of $0.6 \mathrm{~mA}$ with restrained capacity of $500 \mathrm{mAh} / \mathrm{g}$ for discharge and recharge. 
(a)

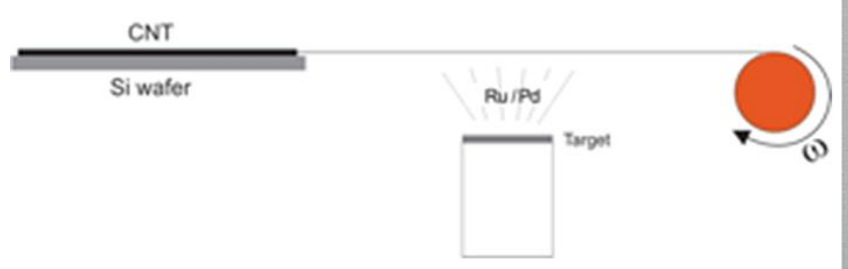

(b) air electrode

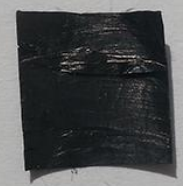

Figure S1. (a) The schematic procedure for the fabrication of noble metal-catalyzed CNT fabric electrodes, (b) the photograph of the obtained CNT cathodes. 

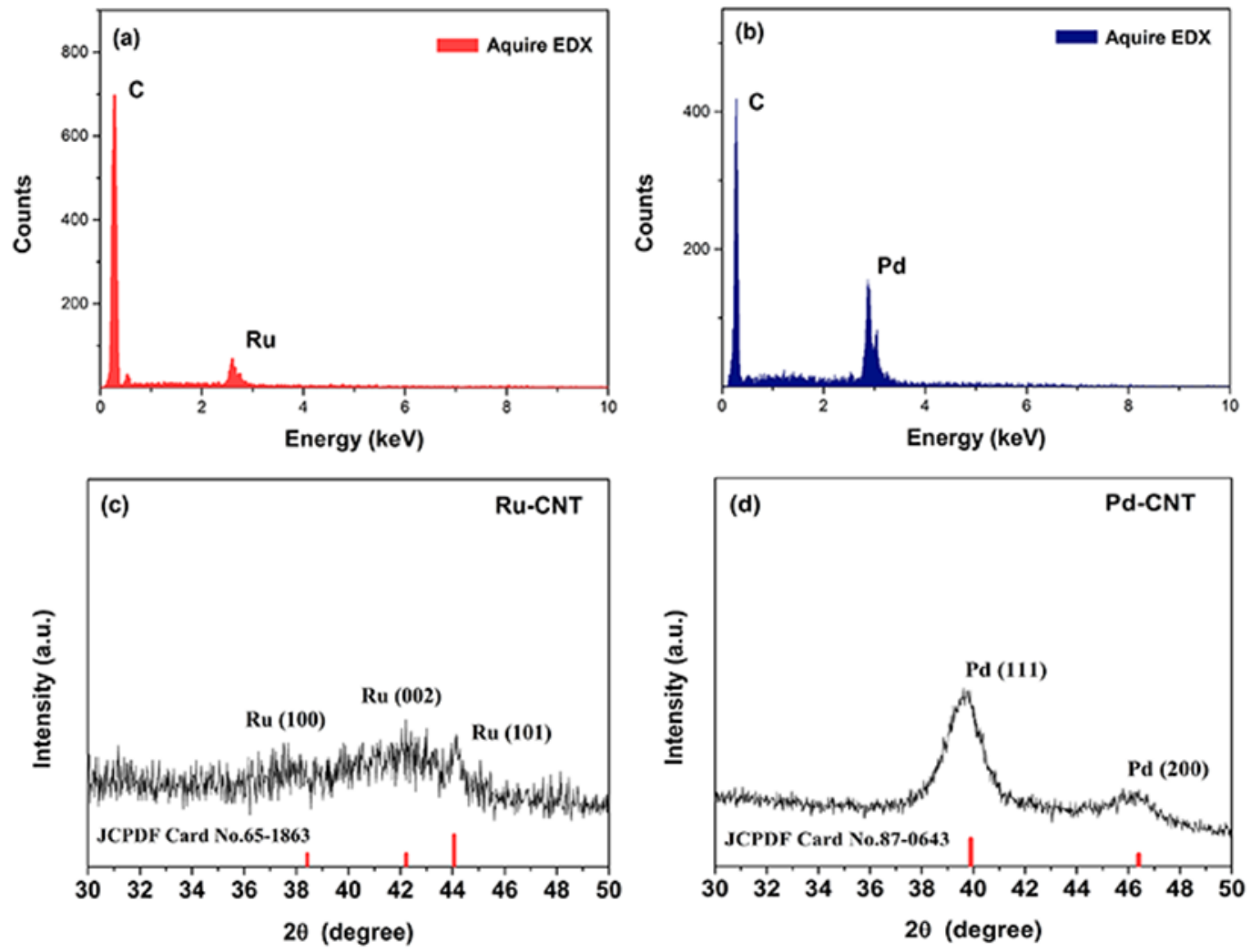

Figure S2. EDX of (a) Ru-CNT and (b) Pd-CNT, and the XRD patterns for (c) $\mathrm{Ru}-\mathrm{CNT}$ and (d) Pd-CNT. 

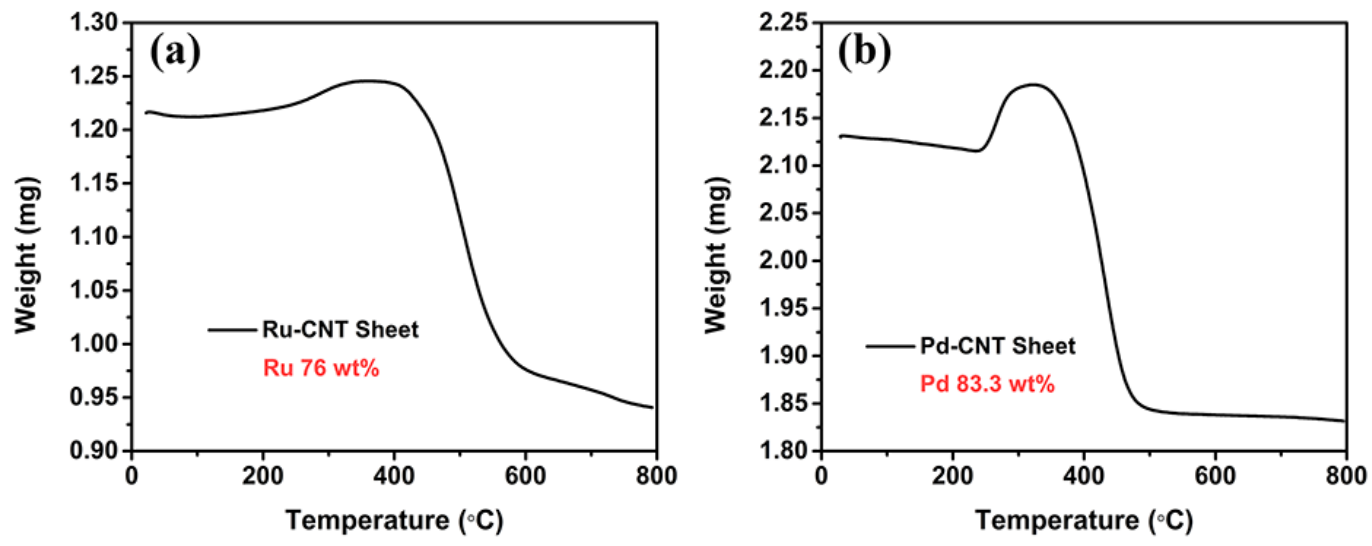

Figure S3. TGA curves of (a) Ru-CNT and (b) Pd-CNT fabric samples. 


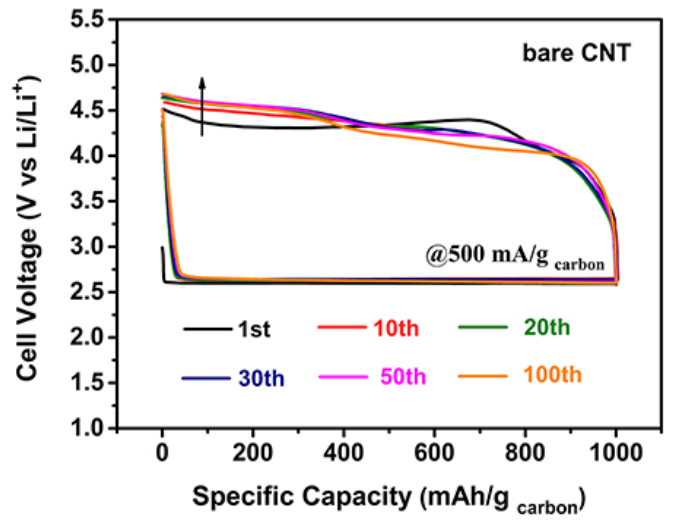

Figure S4. Discharge and recharge curves of the $\mathrm{Li}_{2} \mathrm{O}_{2}$ cells based on the pristine CNT cathode. 

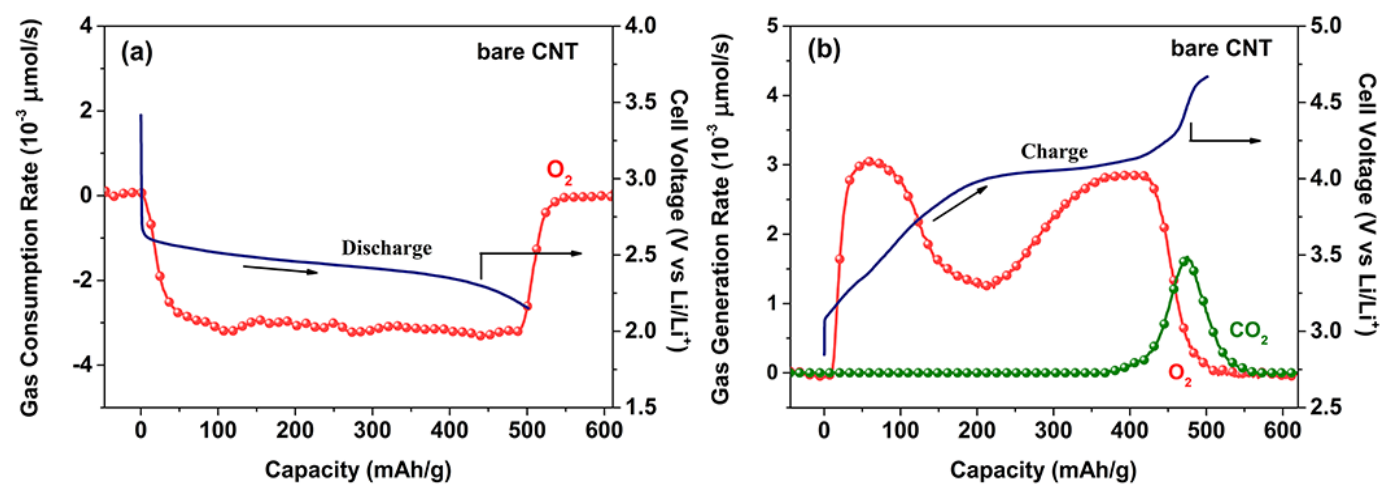

Figure S5. DEMS analysis of gas consumed/evolved during the (a) discharge and (b) recharge of pristine CNT based $\mathrm{Li}^{-} \mathrm{O}_{2}$ cell. 

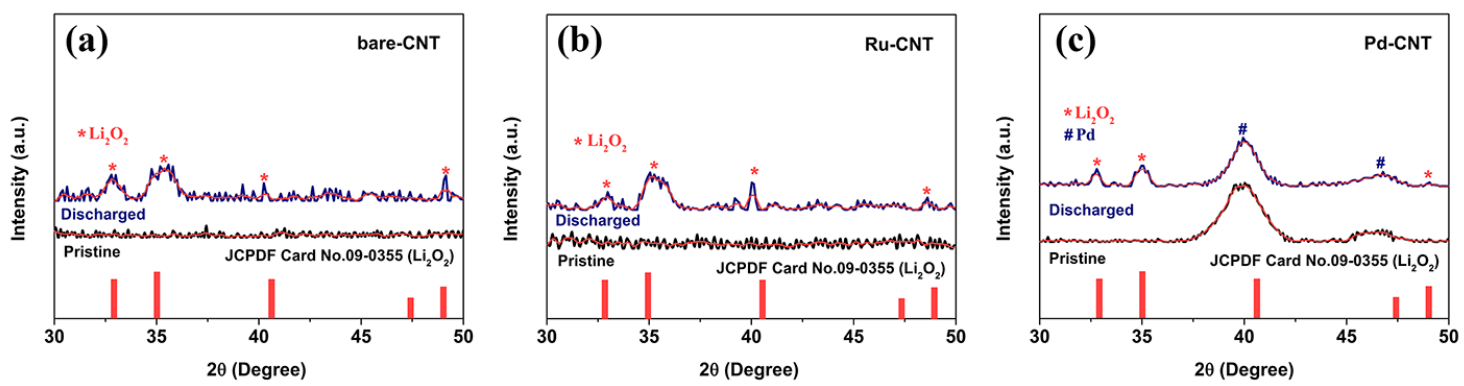

Figure S6.The XRD patterns of (a) bare-CNT, (b) Ru-CNT and (c) Pd-CNT cathodes before and after discharge to a fixed capacity of $1000 \mathrm{mAh} / \mathrm{g}_{\text {carbon }}$. 

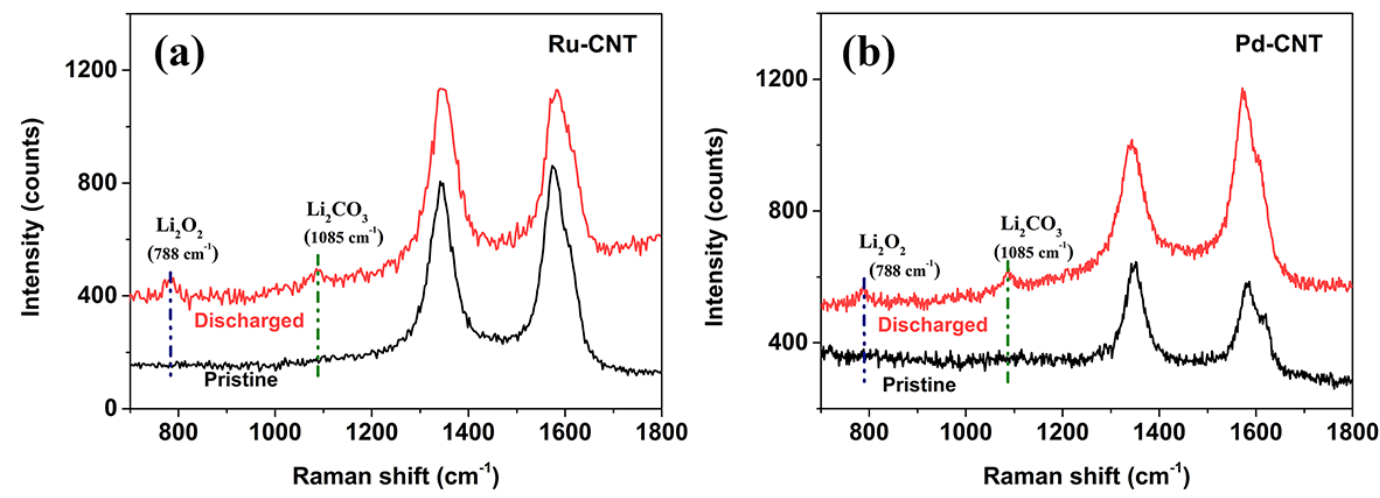

Figure S7.The Raman Spectra of (a) Ru-CNT and (b) Pd-CNT cathodes before and after discharge to a fixed capacity of $1000 \mathrm{mAh} / \mathrm{g}_{\text {carbon }}$. 

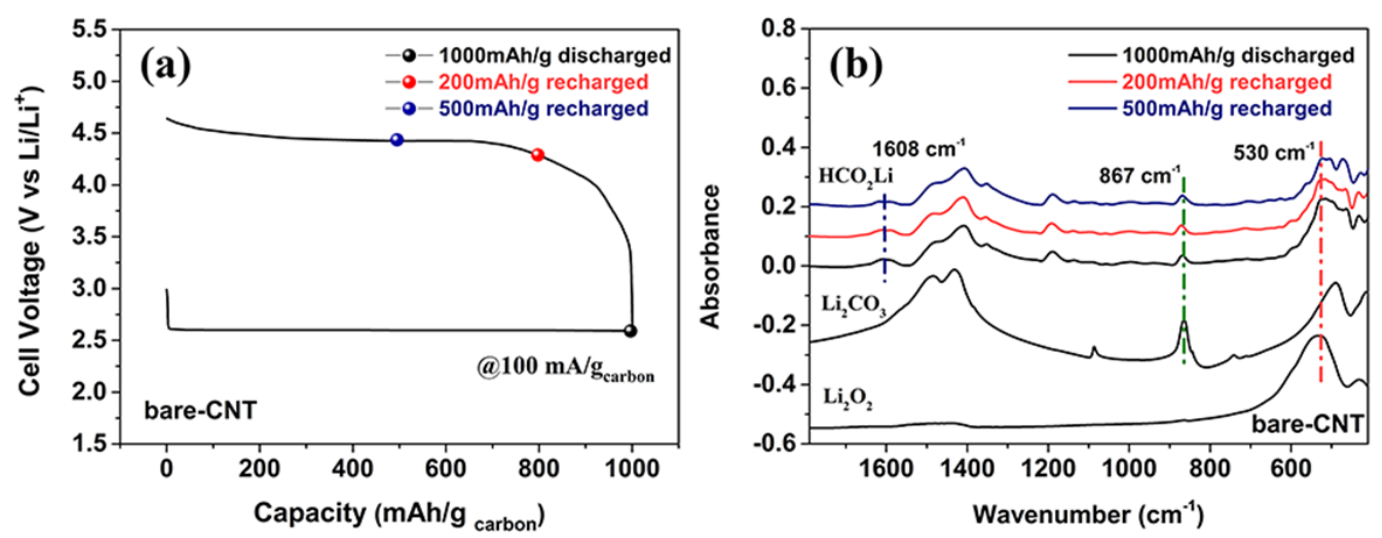

Figure S8. (a) The discharge-recharge voltage profiles of the pristine CNT cathode operated with a fixed capacity of $1000 \mathrm{mAh} / \mathrm{g}_{\text {carbon }}$ at a current density of 100 $\mathrm{mA} / \mathrm{g}_{\text {carbon }}$ (b) FTIR spectra of pristine CNT cathode being charged to different stages, i.e. $0 \mathrm{mAh} / \mathrm{g}, 200 \mathrm{mAh} / \mathrm{g}$ and $500 \mathrm{mAh} / \mathrm{g}$.

Table S1 FTIR intensity of $\mathrm{Li}_{2} \mathrm{O}_{2}, \mathrm{Li}_{2} \mathrm{CO}_{3}$ and $\mathrm{HCO}_{2} \mathrm{Li}$ in pristine CNT cathode being charged to different stages corresponding to Figure S8.

\begin{tabular}{|c|c|c|c|c|}
\hline CNT & $\begin{array}{c}\mathrm{A}\left[\mathrm{Li}_{2} \mathrm{O}_{2}\right] \\
\left(530 \mathrm{~cm}^{-1}\right)\end{array}$ & $\begin{array}{l}\mathrm{A}\left[\mathrm{Li}_{2} \mathrm{CO}_{3}\right] \\
\left(867 \mathrm{~cm}^{-1}\right)\end{array}$ & $\begin{array}{l}\mathrm{A}\left[\mathrm{HCO}_{2} \mathrm{Li}\right] \\
\left(1608 \mathrm{~cm}^{-1}\right)\end{array}$ & $\frac{\mathrm{A}[\mathrm{Li} 2 \mathrm{O} 2]}{\mathrm{A}[\mathrm{Li} 2 \mathrm{CO}]+\mathrm{A}[\mathrm{HCO2Li}}$ \\
\hline $\begin{array}{r}\text { Discharged } \\
\left(1000 \mathrm{mAhg}^{-1}\right)\end{array}$ & 0.217 & 0.033 & 0.018 & 4.26 \\
\hline $\begin{array}{l}\text { Recharged } \\
\left(200 \mathrm{mAhg}^{-1}\right) \\
\end{array}$ & 0.180 & 0.032 & 0.018 & 3.60 \\
\hline $\begin{array}{l}\text { Recharged } \\
\left(500 \mathrm{mAhg}^{-1}\right)\end{array}$ & 0.148 & 0.032 & 0.013 & 3.29 \\
\hline
\end{tabular}



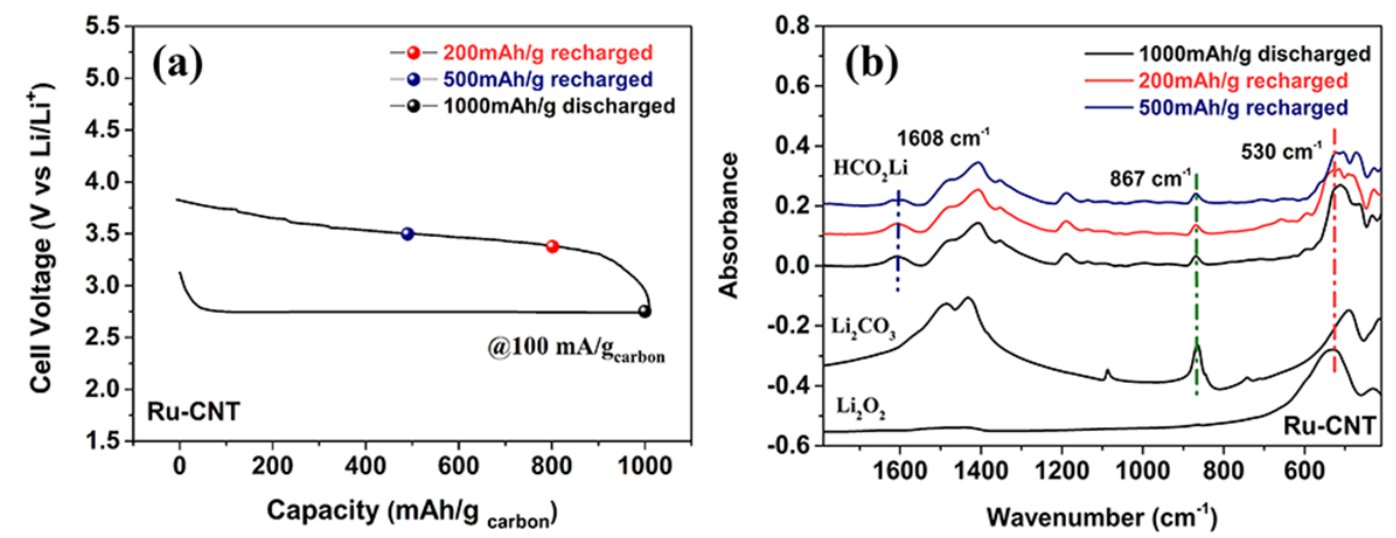

Figure S9. (a) The discharge-recharge voltage profiles of the Ru-CNT cathode operated with a fixed capacity of $1000 \mathrm{mAh} / \mathrm{g}_{\text {carbon }}$ at a current density of 100 $\mathrm{mA} / \mathrm{g}_{\text {carbon }}$ (b) FTIR spectra of Ru-CNT cathode being charged to different stages, i.e. $0 \mathrm{mAh} / \mathrm{g}, 200 \mathrm{mAh} / \mathrm{g}$ and $500 \mathrm{mAh} / \mathrm{g}$.

Table S2 FTIR intensity of $\mathrm{Li}_{2} \mathrm{O}_{2}, \mathrm{Li}_{2} \mathrm{CO}_{3}$ and $\mathrm{HCO}_{2} \mathrm{Li}$ in $\mathrm{Ru}-\mathrm{CNT}$ cathode being charged to different stages corresponding to Figure S9.

\begin{tabular}{|c|c|c|c|c|}
\hline $\mathrm{Ru}-\mathrm{CNT}$ & $\begin{array}{c}\mathrm{A}\left[\mathrm{Li}_{2} \mathrm{O}_{2}\right] \\
\left(530 \mathrm{~cm}^{-1}\right)\end{array}$ & $\begin{array}{l}\mathrm{A}\left[\mathrm{Li}_{2} \mathrm{CO}_{3}\right] \\
\left(867 \mathrm{~cm}^{-1}\right)\end{array}$ & $\begin{array}{l}\mathrm{A}\left[\mathrm{HCO}_{2} \mathrm{Li}\right] \\
\left(1608 \mathrm{~cm}^{-1}\right)\end{array}$ & $\frac{\mathrm{A}[\mathrm{Li} 2 \mathrm{O} 2]}{\mathrm{A}[\mathrm{Li} 2 \mathrm{CO}]+\mathrm{A}[\mathrm{HCO2Li}}$ \\
\hline $\begin{array}{r}\text { Discharged } \\
\left(1000 \mathrm{mAhg}^{-1}\right)\end{array}$ & 0.256 & 0.033 & 0.015 & 5.33 \\
\hline $\begin{array}{l}\text { Recharged } \\
\left(200 \mathrm{mAhg}^{-1}\right) \\
\end{array}$ & 0.221 & 0.034 & 0.015 & 4.51 \\
\hline $\begin{array}{l}\text { Recharged } \\
\left(500 \mathrm{mAhg}^{-1}\right)\end{array}$ & 0.171 & 0.033 & 0.014 & 3.63 \\
\hline
\end{tabular}



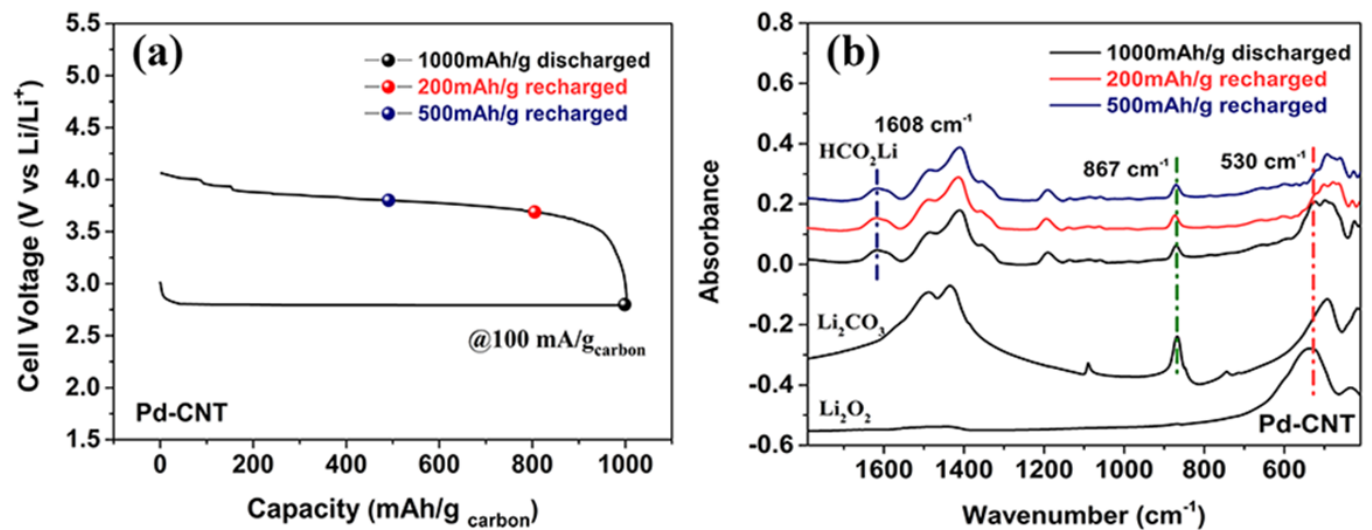

Figure S10. (a) The discharge-recharge voltage profiles of the Pd-CNT cathode operated with a fixed capacity of $1000 \mathrm{mAh} / \mathrm{g}_{\text {carbon }}$ at a current density of 100 $\mathrm{mA} / \mathrm{g}_{\text {carbon }}$ (b) FTIR spectra of Pd-CNT cathode being charged to different stages, i.e. $0 \mathrm{mAh} / \mathrm{g}, 200 \mathrm{mAh} / \mathrm{g}$ and $500 \mathrm{mAh} / \mathrm{g}$.

Table S3 FTIR intensity of $\mathrm{Li}_{2} \mathrm{O}_{2}, \mathrm{Li}_{2} \mathrm{CO}_{3}$ and $\mathrm{HCO}_{2} \mathrm{Li}$ in Pd-CNT cathode being charged to different stages corresponding to Figure S10.

\begin{tabular}{ccccc}
\hline Pd-CNT & $\begin{array}{c}\mathrm{A}\left[\mathrm{Li}_{2} \mathrm{O}_{2}\right] \\
\left(530 \mathrm{~cm}^{-1}\right)\end{array}$ & $\begin{array}{c}\mathrm{A}\left[\mathrm{Li}_{2} \mathrm{CO}_{3}\right] \\
\left(867 \mathrm{~cm}^{-1}\right)\end{array}$ & $\begin{array}{c}\mathrm{A}\left[\mathrm{HCO}_{2} \mathrm{Li}\right] \\
\left(1608 \mathrm{~cm}^{-1}\right)\end{array}$ & $\frac{\mathrm{A}[\mathrm{Li202}]}{\mathrm{A}[\mathrm{Li2CO3}]+\mathrm{A}[\mathrm{HCO2Li}]}$ \\
\hline $\begin{array}{c}\text { Discharged } \\
\left(1000 \mathrm{mAhg}^{-1}\right)\end{array}$ & 0.193 & 0.066 & 0.045 & 1.74 \\
\hline $\begin{array}{l}\text { Recharged } \\
\left(200 \mathrm{mAhg}^{-1}\right)\end{array}$ & 0.142 & 0.064 & 0.047 & 1.28 \\
\hline $\begin{array}{l}\text { Recharged } \\
\left(500 \mathrm{mAhg}^{-1}\right)\end{array}$ & 0.100 & 0.064 & 0.046 & 0.91 \\
\hline
\end{tabular}

